\title{
THE CORRELATION BETWEEN EXERCISE ACTIVITY, GENETIC BACKGROUND, FAST FOOD CONSUMPTION, AND DYSMENORRHEA
}

\author{
Hubungan antara Aktivitas Olahraga, Riwayat Keluarga dan Konsumsi Fast Food dengan Kejadian \\ Dismenore \\ Dewi Mariatus Sholihah \\ Department of Epidemiology, Public Health Faculty, Universitas Airlangga, dewilika40@yahoo.co.id \\ Corresponding Author: Dewi Mariatus Sholihah, dewilika40@yahoo.co.id, Department of Epidemiology, \\ Public Health Faculty, Universitas Airlangga, Dr. Ir. H. Soekarno, Mulyorejo, Surabaya City, East Java, \\ Indonesia, Postal Code 60115
}

\section{ARTICLE INFO}

Article History:

Received April, $16^{\text {th }}, 2019$

Revised form May, $9^{\text {th }}, 2019$

Accepted July, 17 ${ }^{\text {th }}, 2019$

Published online August, 30 ${ }^{\text {th }}, 2019$

\section{Keywords: \\ exercise activity; genetic background; fast food consumption; dysmenorrhea}

\section{Kata Kunci:}

aktivitas olahraga; riwayat keluarga; konsumsi fast food; dismenore

\begin{abstract}
Background: Most women in Indonesia have experienced dysmenorrhea $(54.89 \%)$. One of the factors that influence dysmenorrhea is low preventive measures carried out by women such as lack of exercise activity, genetic background, and consumption of fast food. Purpose: This study aims to analyze the correlation between exercise activity, genetic background, and fast food consumption and dysmenorrhea. Method: This study was an analytic observational study with a cross-sectional research design. The research population included the students of Public Health Faculty who had menstruated. The samples were 108 respondents chosen by random sampling technique. The variables examined in this study were genetic background, exercise activity, and fast food consumption and the occurrence of dysmenorrhea. Data collection was carried out in February 2019. The research location was at the Faculty of Public Health, Universitas Airlangga, Surabaya. The data were analyzed using univariate and bivariate analysis based on the chi-square test results. Result: The prevalence of dysmenorrhea experienced by students of Public Health Faculty was $65.70 \%$. The test results showed no correlation between exercise activity and dysmenorrhea $(\mathrm{p}=0.47)$, there was a correlation between dysmenorrhea and genetic background $(p=0.01)$ and there was no correlation between consumption of fast food and dysmenorrhea $(p=0.53)$. Conclusion: The study shows the there is a correlation between genetic background and dysmenorrhea. On the other hand, there is no correlation between exercise activity and the consumption of fast food with the occurrence of dysmenorrhea.
\end{abstract}

C2019 Jurnal Berkala Epidemiologi. Published by Universitas Airlangga.

This is an open-access article under CC-BY-SA license (https://creativecommons.org/licenses/by-sa/4.0/)

\section{ABSTRAK}

Latar Belakang: Sebagian besar perempuan di Indonesia pernah mengalami dismenore (54,89\%). Salah satu faktor yang mempengaruhi kejadian dismenore yaitu masih rendahnya upaya preventif yang dilakukan oleh perempuan seperti kurangnya aktivitas olahraga, ada riwayat keluarga dan konsumsi fast food. Tujuan: Penelitian ini bertujuan untuk melakukan analisis hubungan antara 
aktivitas olahraga, riwayat keluarga dan konsumsi fast food terhadap kejadian dismenore. Metode: Penelitian ini merupakan penelitian observasional analitik dengan desain penelitian cross sectional. Populasi dalam penelitian ini adalah seluruh mahasiswi Fakultas Kesehatan Masyarakat yang sudah mengalami menstruasi. Jumlah sampel penelitian sebanyak 108 responden dengan teknik pengambilan sampel random sampling. Variabel yang diteliti dalam penelitian ini yaitu riwayat keluarga, aktivitas olahraga dan konsumsi fast food dengan kejadian dismenore. Pengambilan data dilakukan pada bulan Februari 2019. Lokasi penelitian yaitu pada Fakultas Kesehatan Masyarakat Universitas Airlangga Kota Surabaya. Teknis analisis data dilakukan dengan menggunakan analisis univariat dan bivariat yang didasarkan dari hasil uji statistik chi square. Hasil: Prevalensi kejadian dismenore pada mahasiswi Fakultas Kesehatan Masyarakat adalah 65,70\%. Hasil uji menunjukkan tidak ada hubungan antara aktivitas olahraga dengan dismenore $(p=0,47)$, ada hubungan antara dismenore dengan riwayat keluarga $(p=0,01)$ dan tidak ada hubungan antara konsumsi fast food dengan dismenore $(p=0,53)$. Kesimpulan: Terdapat hubungan antara riwayat keluarga dengan dismenore. Tidak terdapat hubungan antara aktivitas olahraga dan konsumsi fast food dengan kejadian dismenore.

C2019 Jurnal Berkala Epidemiologi. Penerbit Universitas Airlangga. Jurnal ini dapat diakses secara terbuka dan memiliki lisensi CC-BY-SA (https://creativecommons.org/licenses/by-sa/4.0/)

\section{INTRODUCTION}

Adolescence is the period when people experience physical and psychological changes. It also changes their social expectation and perception. One of the maturity signs is physical growth and development, accompanied by secondary sex (puberty), and sexual and reproductive maturity. The number of adolescence in the world is 1.20 million (UNICEF, 2011). According to the population projection book, in 2018, Indonesia had 33 thousand young girls with an age range between 10-24 years old. The number young girls of East Java reaches 4,484 people, whereas, in Surabaya alone, the figure amounts to 353 people (Indonesian Central Bureau of Statistics, 2013). Adolescence is the future generation who requires to maintain their health because many diseases affect adolescence survival (UNICEF, 2011). Dysmenorrhea is a health problem faced by women which has symptoms such as pain with various degrees. It is experienced by most young women every month during their menstruation period. Besides, menstrual pain or dysmenorrhea is an increase of uterine contraction that occurs before, even during menstruation. On the first or second day is dysmenorrhea that is commonly experienced by teenagers on their menstrual period (Khairunnisa \& Maulina, 2018).

There are $90.00 \%$ of Indonesian women who have got dysmenorrhea. In this circumstance, most women do not take prevention to reduce menstrual pain. The prevention act include conducting checkup or consulting with a doctor (Rahayu, Pertiwi, \& Patimah, 2017). Primary dysmenorrhea is felt maximally by women with an age range between 15-25 years old (Ammar, 2016). It also can bother someone's social activities and routines (Savanthe \& Nanjundappa, 2015). There are two kinds of dysmenorrhea, primary and secondary dysmenorrhea. Primary dysmenorrhea is a pain felt by women who have not got pregnant or reproductive abnormalities on menstrual period. While, secondary dysmenorrhea is a pain experienced by women who have genital abnormalities. In fact, there are $54.89 \%$ primary dysmenorrhea and $9.36 \%$ secondary dysmenorrheal experienced by Indonesian women (Fahimah, Margawati, \& Fitranti, 2017).

The previous research showed that $60.20 \%$ of the respondents, from SMA Al-Azhar, one of Islamic schools in Surabaya, experienced inconvenience during their menstruation, i.e., $30.60 \%$ of dysmenorrhea and $30.60 \%$ of PreMenstrual Syndrome or PMS (Novita, 2018). 
According to the study, the effects of dysmenorrhea were capable of disturbing the lesson or schooling period, and loss of work time and productivity. In a similar circumstance, Khairunnisa \& Maulina (2018) suggested that $97.90 \%$ of students experience dysmenorrhea.

The research conducted by Sakinah (2016) stated that most of the students in $10^{\text {th }}$ and $11^{\text {th }}$ grade of Kornita Bogor Senior High School experienced dysmenorrhea (74.10\%). Some of the symptoms experienced by the students include dizziness, vomiting, queasy, headache, and body aches. These symptoms, thus, affect their activity. Based on the study, the result shows that most of female students get dysmenorrhea only do their easy activity $(73.30 \%)$.

The research conducted by Handayani \& Rahayu (2014) asserted that the risk factors of dysmenorrhea include age, irregular exercise $(82.50 \%)$, and genetic background (95\%). Women who rarely work out have a chance to get dysmenorrhea during menstruation. In this case, it is caused by vasoconstriction of the reproductive organ during menstruation, and it causes the oxygen cannot be distributed to the blood vessel. Therefore, it can be reduced by exercising regularly.

According to Indahwati, Muftiana, \& Purwaningroom (2017) in their study, most of the female teenagers with dysmenorrhea consume fast food frequently (55.60\%). Consuming fast food excessively can cause obesity. Then, one of the obesity characteristics is double stomach which is caused by excess fat. The high fat will trigger adipose tissue to produce hormones in an abnormal amount such as high insulin secretion, high level of testosterone and free androstenedione, and low level of progesterone. this condition can stimulate androgen production in the ovary. Then, it will affect and interfere with normal ovulation that causes abnormality during menstruation, namely menstrual pain (Rakhma, 2012). The factors that influence dysmenorrhea include exercise activity, genetic background and consuming fast food. The purpose of this study is to analyze the correlation between exercise activity, genetic background, and consuming fast food and dysmenorrhea on female students of Public Health Faculty of Universitas Airlangga, Surabaya.

\section{METHODS}

This study was an analytic observational study with a cross-sectional design. The research population was all undergraduate female students of Public Health Faculty, Universitas Airlangga who had got menstruation, amounting to 1,217 students. The samples were taken by using the calculation of Lemeshow sample as follows:

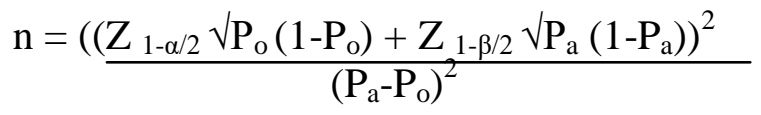

Based on the calculation above, the result showed that the required research samples were 108 people. The calculation adapted the proportion of research that is similar to the initial proportion value with primary dysmenorrhea of 0.75 , and the final proportion is 0.85 . This study used $5 \%$ alpha and $80 \%$ beta value. The inclusion criteria of this study include women with age range between 1525 years old who had menstruation regularly, and were included into primary dysmenorrhea (had no genital abnormalities or disease and never got pregnant).

The sampling technique of the study was simple random sampling. In addition, the study subject was taken randomly from female undergraduate students of Public Health Faculty of UNAIR, based on the attendance list in every class. The obtained data sources included primary data from questionnaires and the data of Public Health Faculty female students as the secondary data. The data were collected in February, 2019, in the campus of Public Health Faculty, Universitas Airlangga, Surabaya.

There were two variables in this study; dependent variable, i.e., dysmenorrheal occurrence, that was obtained from the questionnaires about the pain during menstruation; and the independent variables including exercise activity, genetic background, and fast food consumption. In this circumstance, the exercise variable was based on the exercise intensity done by the research subjects. The variables were classified into frequent and rare exercises. Indeed, the exercise activities are regarded as "frequent', if the subject of the study do the exercise $\geq 3$ times a week with intensity of at least 30 minutes a day, while, if the subject do the exercise < 3times with the intensity of less than 30 minutes, it is classified into "rare" exercise activities. Genetic background refers to the family members' history of dysmenorrhea during menstruation. In addition, the variable of fast food consumption is divided into two categories, frequent and rare. A subject is included in the frequent category if he/she consumed fast food $\geq 3$ times a week. However, if 
the subject consumed fast food $<3$ times a week, he/she is categorized into "rare".

This study used univariate analysis technique that was obtained from the result of the variable frequency distribution of dysmenorrhea, exercise activity, genetic background, and fast food consumption. Besides, this study also used bivariate analysis technique by using the chisquare test to find out the correlation between genetic background, exercise activity, consuming fast food and dysmenorrhea.

\section{RESULTS}

Most female students of Public Health Faculty, Universitas Airlangga have experienced dysmenorrhea (65.74\%). Most of them do exercises rarely $(57.41 \%)$. The result of the statistical test shows that there is a significant correlation between exercise activities and dysmenorrhea. It can be seen by $p$-value $=0.54$ (Table 1).

Most respondents with dysmenorrhea had genetic background of dysmenorrhea (39.81\%). The test indicated a p-value of 0.01 , which means that there is a correlation between genetic background and dysmenorrhea (Table 1). On the other hand, most of the dysmenorrhea respondents are rare to consume fast food $(53.70 \%)$. From the statistical test, consuming fast food variable does not correlate with dysmenorrhea in which p-value of 0.53 (Table 1).

\section{DISCUSSION}

\section{The Correlation between Exercise Activity and Dysmenorrhea}

Dysmenorrhea is a pain experienced by women and felt when the uterus contracts during menstruation with different levels of pain. The levels of pain include low, average, high pain. During menstruation, women usually feel the pain in the back and lower abdomen. Dysmenorrhea usually is occurred before or during menstruation (Sakinah, 2016).

The results of this research show that most respondents of Public Health Faculty Universitas Airlangga have dysmenorrhea during their menstruation. It is also supported by Mohapatra, Mishra, Behera, \& Panda (2017) that state most of the respondents have dysmenorrhea, amounting to
148 people where 90 of them feel the average pain (45\%).

Furthermore, this study shows that there is not a significant correlation between exercise activity variable with the dysmenorrhea experienced by respondents. It is also supported by Kazama, Maruyama, \& Nakamura (2015) who assert that there is no correlation between exercise habits and dysmenorrhea. most of the respondents $(49.70 \%)$ are not used to exercise. In addition, another study also shows a similar result in which although most of the female teenagers $(63.20 \%)$ do not do exercise activities, the statistical test shows no significant correlation (Ibrahim et al., 2015).

However, the study of Sirait, Hiswani, \& Jemadi (2014) shows the different result that there is a correlation between exercise activities and dysmenorrhea as shown by the value $\mathrm{p}=0.04$. In this case, the study states that people who do exercises regularly will produce the hormones that can bind to the receptor in the brain, namely the endorphin hormone.

The hormone includes alpha, beta, and gamma endorphin. Function of those hormones is to mediate the pain perception. Exercise regularly is one of the factors that relates to dysmenorrhea. People who do not exercise will have greater chance to get dysmenorrhea 3.48 times than people who do it (Handayani \& Rahayu, 2014).

Furthermore, Rakhma (2012) also asserts that exercise activities have a correlation with dysmenorrhea. The pain felt by women can be reduced by doing movement in which is doing exercise activities. In this case, doing exercise regularly can facilitate the flow of oxygen to the reproductive organ through blood vessels so that the pain will be reduced during menstruation.

Exercise activity is one way to reduce the duration, severity, and intensity of dysmenorrhea. The quality of exercises such as intensity of time and moving activeness in different exercises will affect the level of dysmenorrhea felt by women. If someone does exercise regularly even once a week or time less than 30 minutes, then, dysmenorrhea level experienced will be the same with someone who do strenuous exercise irregularly. There are physical activities done to reduce dysmenorrhea such as jogging, gymnastics, cycling, or swimming (Agustini, 2017). Besides, the other study also states that dysmenorrhea will reduce when it is balanced with the exercise activities (Kusmindarti $\&$ Munadlifah, 2016). 
Table 1

The Correlation between Exercise Activity, Genetic Background, and Fast Food Consumption and Dysmenorrhea

\begin{tabular}{|c|c|c|c|c|c|c|c|}
\hline \multirow{3}{*}{ Variable } & \multicolumn{4}{|c|}{ Dysmenorrhea Occurrence } & \multirow{2}{*}{\multicolumn{2}{|c|}{ Total }} & \multirow{3}{*}{$\mathrm{p}$-value } \\
\hline & \multicolumn{2}{|c|}{ Yes } & \multicolumn{2}{|c|}{ No } & & & \\
\hline & $\mathrm{n}$ & $\%$ & $\mathrm{n}$ & $\%$ & $\mathrm{n}$ & $\%$ & \\
\hline \multicolumn{8}{|l|}{ Exercise activity } \\
\hline Rare & 62 & 57.41 & 34 & 31.48 & 96 & 88.89 & 0.54 \\
\hline Frequent & 9 & 8.33 & 3 & 27.78 & 12 & 11.11 & \\
\hline \multicolumn{8}{|c|}{ Genetic Background } \\
\hline Yes & 43 & 39.81 & 13 & 12.04 & 56 & 51.85 & 0.01 \\
\hline No & 28 & 25.93 & 24 & 22.22 & 52 & 48.15 & \\
\hline \multicolumn{8}{|c|}{ Fast Food Consumption } \\
\hline Rare & 13 & 12.04 & 5 & 4.63 & 18 & 16.67 & 0.53 \\
\hline Frequent & 58 & 53.70 & 32 & 29.63 & 90 & 83.33 & \\
\hline Total & 71 & 65.74 & 37 & 34.20 & 108 & 100.00 & \\
\hline
\end{tabular}

Study conducted by Khairunnisa \& Maulina (2018) also asserts that dysmenorrhea or menstrual pain felt by female teenagers during menstruation will diminish if they do exercise regularly. They also show that dysmenorrhea also is influenced by other factors such as nutritional status, age, history of stress in the family, intense menstrual flow, and hormone. Everyone has different levels of hormones, in order that, it will have a different impact on the pain experienced during menstruation. The nutritional status also affects the pain felt by women during menstruation. Someone's nutritional status is good if foods or substances consumed meet to their needs. People who experience menstruation at young have greater risk to get dysmenorrhea than the adult. In this circumstance, at young age, the body has not been ready yet to face the changes of reproductive organs, so that the pain will arise. Next, Rahayu, Pertiwi, \& Patimah (2017) state that other factors that cause dysmenorrhea such as stress, exercise, and foods. The stress factor is a psychological factor that affects someone to handle the problems.

In addition, the research conducted by Cholifah \& Hadikasari (2015) shows that there is a relation between exercise regularly with pain as indicated by $\mathrm{p}$-value of 0.00 . One of the factors that cause teenagers to lack of exercise activities is limited time. Most adolescence uses the time to join in the school or campus activity. If there is leisure time enough, they will spend to take a rest.

\section{The Correlation between Genetic Background and Dysmenorrhea}

Most of Public Health students of Universitas Airlangga who get dysmenorrhea also have a family member who also experiences dysmenorrhea. This study relates to the study of Sirait, Hiswani, \& Jemadi (2014) that most of dysmenorrhea respondents have the genetic background of dysmenorrhea (57.80\%). Moreover, it is also supported by Kristianingsih (2016) who states that most female junior high school students in South Lampung have a family history of dysmenorrhea $(81.60 \%)$.

The result of this present study shows that there is a correlation between the genetic background variable and Dysmenorrhea of Public Health students of Universitas Airlangga. It is caused that family history is one of genetic factors. so that it may happen the same thing to their descendant. Besides, it also relates to the research of Sirait, Hiswani, \& Jemadi (2014) who assert that there is a correlation between genetic background and dysmenorrhea with the p-value of 0.01. Women with genetic background of Dysmenorrhea have greater risk to get Dysmenorrhea comparing to women who do not. It is one of dysmenorrhea factors that cannot be changed. Besides, it is the factor that affects the health of the family, and supports the same disease. The genetic background is also associated with endometriosis in which cause of female pelvic pain on reproductive age. Endometriosis is an abnormality growth condition of cells found in the endometrium. Therefore, it causes pain during menstruation or it is called dysmenorrhea.

The research conducted by Handayani \& Rahayu (2014) shows the same result that there is a significant correlation between genetic background and dysmenorrhea ( $p$-value $=0.01$ ) because genetic background can affect dysmenorrhea. It needs prevention for women if they have a genetic background of dysmenorrhea. 
It relates to the study conducted by Pejc ic \& Jankovic (2016) about dysmenorrhea risk factors of the students who state that the significant relation between the genetic background and dysmenorrhea. Besides, it also shows that women Dysmenorrhea genetic background has a greater risk of getting dysmenorrhea 3.49 times than women do not have.

The absence of dysmenorrhea family members will contribute dysmenorrhea to their descendant (Ammar, 2016). Then, it also explains that genetic background and dysmenorrhea have significant correlation with 0,01 . Most women who get dysmenorrhea have family members such as mother or kinship who get dysmenorrhea. It is caused by the presence of dysmenorrhea genetic factor. The study conducted by Faramarzi \& Salmalian (2014) also state that there is a correlation between genetic background with dysmenorrhea. It explains that a daughter of mother who has dysmenorrhea during menstruation will feel the same thing. It may be caused by the behavior learned as the mother does.

\section{The Correlation between Fast Food Consumption and Dysmenorrhea}

Most of Public Health Faculty female students in Universitas Airlangga consume fast food rarely and feel dysmenorrhea. The result is different from the research that is conducted by Indahwati, Muftiana, \&Purwaningroom (2017) who assert that most respondents of dysmenorrhea consume fast food frequently. Fast food is a food containing high fat, sodium, and low micronutrient. Therefore, it is not good to be consumed on daily basis. Most contents of fast food are high sugar, sodium, fat, and calories. The other contents are low vitamin $\mathrm{A}$ and $\mathrm{C}$, calcium, fiber, and folate. Someone who likes to eat fast food does not fulfill their nutritional needs and will affect the health of reproductive organ. The fast food will also affect the metabolism of progesterone during the menstrual luteal phase. It will cause pain influenced by increasing prostaglandin levels. Another consequence of consuming fast food is the abnormalities of menstruation cycle such as oligomenorrhea hypermenorrhea and pre-menstrual syndrome (Larasati \& Alatas, 2015). Consuming fast food is one of the factors that has significant correlation toward dysmenorrhea. The study also explains that women of dysmenorrhea should consume low fat and high fiber foods. It is caused the foods can reduce the estrone level of serum sulfate in which serve to reduce the pain during menstruation (Farasati et al., 2015).

The study also found that there was no correlation between consuming fast food with dysmenorrhea of Public Health Faculty female students, Universitas Airlangga. It is caused most of the respondents have the same habits that they consume fast food rarely. The respondents have understood that fast food is not a good food and will affect the health. One of the effects of consuming fast food is women will have the pain or dysmenorrhea during menstruation (Halpern, Schor, \& Kopelman, 2016).

Fast food is food which contains high fat and sugar. It is not good for health because it is addictive. The bad content of foods will cause dysmenorrhea to women. The higher consumption of fast food will affect to the menstruation cycle and the level of dysmenorrhea felt by women (Pramanik \& Dhar, 2014).

\section{CONCLUSION}

There is a significant correlation between genetic background and dysmenorrhea. On the other hand, exercise activities and consuming fast food do not correlate toward dysmenorrhea on female students of Public Health Faculty, Universitas Airlangga, Surabaya. It is caused most of the respondents have similar habits.

\section{ACKNOWLEDGMENT}

The author would like to extend her utmost gratitude to all Public Health Faculty students, Universitas Airlangga Surabaya who have made time and were willing to be the research respondents.

\section{REFERENCES}

Agustini, F. U. (2017). Relationship between eating habits, physical activity, and nutritional status with the incidence of dysmenorrhea in female students PPKU IPB. Undergraduated Thesis. Faculty of Human Ecology. Institut Pertanian Bogor.

Ammar, U. R. (2016). Primary risk factors for dysmenorrhea in women of childbearing age in the Village of Ploso, Tambakari Subdistrict, Surabaya. Jurnal Berkala Epidemiologi, 4(1), 37-49. https://doi.org/10.20473/jbe.v4i1.37-49

Cholifah, \& Hadikasari, A. A. (2015). Relationship between anemia, nutritional 
status, exercise, and knowledge with the incidence of dysmenorrhea in young women. Midwiferia, $\quad$ (1), 31-43. https://doi.org/10.21070/mid.v1i1.346

Fahimah, Margawati, A., \& Fitranti, D. Y. (2017). Relationship between consumption of omega-3 fatty acids, physical activity and percent body fat with levels of dysmenorrhea in adolescents. Journal of Nutrition College, 6(4), 268-276.

Faramarzi, M., \& Salmalian, H. (2014). Association of psychologic and nonpsychologic factors with primary dysmenorrhea. Iranian Red Crescent Medical Journal, 16(8), 1-9. https://doi.org/10.5812/ircmj.16307

Farasati, N., Siassi, F., Koohdani, F., Qorbani, M., Abashzadeh, K., \& Sotoudeh, G. (2015). Western dietary pattern is related to premenstrual syndrome: a case-control study. British Journal of Nutrition, 114(12), $1-6$.

https://doi.org/10.1017/s0007114515003943

Halpern, G., Schor, E., \& Kopelman, A. (2016).

Nutritional aspects related to endometriosis. Revista Da Associação Médica Brasileira, 61(6),

519-523.

https://doi.org/10.1590/1806-9282.61.06.519

Handayani, E. Y., \& Rahayu, L. S. (2014). FaktorFactors that associated with menstrual pain (dysmenorrhoea) in young women in several high schools in Rokan Hulu Regency. Jurnal Maternity and Neonatal, 1(4), 161-171.

Ibrahim, N. K., Alghamdi, M. S., Al-Shaibani, A. N., Alamri, F. A., Alharbi, H. A., Al-Jadani, A. K., \& Alfaidi, R. A. (2015). Dysmenorrhea among female medical students in king abdulaziz university: prevalence, predictors and outcome. Pakistan Journal of Medical Sciences, 31(6), 13121317.

https://doi.org/10.12669/pjms.316.8752

Indahwati, A. N., Muftiana, E., \& Purwaningroom, D. L. (2017). Relationship between eating fast food (fast food) and the incidence of dysmenorrhea in young women at Ponorogo "1" Junior High School. Indonesian Journal for Health Sciences, 1(2), 7-13. https://doi.org/10.24269/ijhs.v1i2.2017.4

Indonesian Central Bureau of Statistics. (2013). Projected Population of Indonesia 20102035. Jakarta: Indonesian Central Bureau of Statistics.

Kazama, M., Maruyama, K., \& Nakamura, K. (2015). Prevalence of dysmerorrhea and its correlating lifestyle factors in Japanese Female Junior High School Students. The Tohoku Journal of Experimental Medicine, 236(2), https://doi.org/10.1620/tjem.236.107

Khairunnisa, \& Maulina, N. (2018). Relationship between physical activity and menstrual pain (dysmenorrhoea) in female students of Ulumuddin Private Islamic School Uteunkot Conda Lhokseumawe City. Averrous, 3(1), 10-20.

Kristianingsih, A. (2016). Primary risk factors of dysmenorrhea at junior high school students in Natar Subdistrict, South Lampung Regency. Jurnal Aisyah: Jurnal Ilmu Kesehatan, 1(1), 19-27. https://doi.org/10.30604/jika.v1i1.4

Kusmindarti, I., \& Munadlifah, S. (2016). Relationship between exercise habits and dysmenorrhea incidence at young women in the Aerobic Gymnastics Community of Dr. Tri Widodo Basuki Jabon Mojoanyar Mojokerto. Jurnal Kebidanan, 5(1), 1-6.

Larasati, T., \& Alatas, F. (2015). Primary dysmenorrhea and risk factors for primary dysmenorrhea in adolescents. Majoritiy, 5(3), 79-84.

Mohapatra, D., Mishra, T., Behera, M., \& Panda, P. (2017). A study of relation between body mass index and dysmenorrhea and its impact on daily activities of medical students. Asian Journal of Pharmaceutical and Clinical Research, 9(3), 297-299. https://doi.org/10.22159/ajpcr.2016.v9s3.147 53

Novita, R. (2018). Relationship between nutritional status and menstrual disorders in young women at Al-Azhar High School Surabaya. Amerta Nutrition, 2(2), 172-181. https://doi.org/10.20473/amnt.v2.i2.2018.172 $-181$

Pejc `ic, A., \& Jankovic, S. (2016). Contrasting the anti-vaccine prejudice: a public health perspective. Ann Ist Super Sanità, 52(1), 98 103. https://doi.org/10.4415/ANN_16_01_16

Pramanik, P., \& Dhar, A. (2014). Impact of fast food on menstrual helath of school going adolescent girls in West Bengal, Eastern India. Global Journal of Biology, Agriculture and Health Sciences, 3(1), 61-66.

Rahayu, A., Pertiwi, S., \& Patimah, S. (2017). Effect of endorphine massage on the pain of dysmenorrhea at midwifery polytechnic students of the Ministry of Health of Tasikmalaya in 2017. Jurnal Bidan "Midwife 
Journal," 3(2), 22-30.

Rakhma, A. (2012). An overview of the degree of dysmenorrhea and its handling efforts on the Arjuna Depok High School Vocational Students in West Java. Undergraduated Thesis. Faculty of Medicine and Health Sciences. Universitas Islam Negeri Syarif Hidayatullah Jakarta.

Sakinah. (2016). Factors related to the incidence of primary dysmenorrhea in adolescents. Undergraduated Thesis. Faculty of Human Ecology. Institut Pertanian Bogor.

Savanthe, A., \& Nanjundappa, V. (2015). Menstruation: a cross-sectional study on knowledge, belief, and practices among adolescent girls of junior colleges, Kuppam, Andhra Pradesh. International Journal of Medical Science and Public Health, 5(1), 2227. https://doi.org/10.5455/ijmsph.2016.1006201 57

Sirait, D. S. O., Hiswani, \& Jemadi. (2014). Factors related to the incidence of dysmenorrhea in 2014 "2" Senior High School Medan Students. Jurnal Gizi, Kesehatan Reproduksi dan Epidemiologi, 1(4), 1-10.

UNICEF. (2011). Adolescence an age of opportunity: the state of the world's children 2011. New York: United Nations Children's Fund. Retrieved May, 22 from https://www.refworld.org/docid/4d6cfa162.ht $\mathrm{ml}$ 